\title{
Succeeding as a Western Academic Working at a Newer Foundation University in a Developing Country
}

Joseph J. Kaminski, International University of Sarajevo, Bosnia and Herzegovina

ABSTRACT This article discusses the two most important things that I have learned since taking a full-time position in 2014 at a newer private university in the Balkans: (1) the unique challenges you face when doing research in such a setting; and (2) how to handle the significant cultural differences that you will face in the classroom. This article also offers recommendations for earning the trust of students who will be suspicious of your motivation for teaching in their country. If you can manage these two realities, you will have a much easier time finding personal fulfillment and, ultimately, professional success in your new endeavor. This article focuses primarily on teaching in newer, private institutions known as Foundation Universities in developing countries more than longestablished public institutions. However, you most certainly will face issues in these public institutions similar to those at smaller private ones.

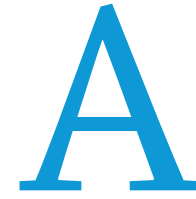
ccepting an academic position in a developing country is both exciting and frightening. As a Muslim convert who studies Islamic political thought, I naturally wanted to teach in a Muslimmajority country. However, because I have never lived for an extended period outside of the United States, I knew that I was going to have to make major lifestyle and teaching adjustments, but I was not quite sure of what they might be. Now in my sixth year of working at a private university in Sarajevo, I have learned what those major adjustments are. This article explores what you should consider before buying your one-way airplane ticket to work in a developing country.

\section{THE REALITIES OF RESEARCH AT A FOUNDATION UNIVERSITY IN A DEVELOPING COUNTRY: A BRIEF OVERVIEW}

Foundation Universities (FUs) refer to those that were established by private foundations often established by a wealthy benefactor or group of businesspeople. Most FUs have bachelor's, master's, and even doctoral programs, as well as laboratories and libraries. The number of FUs in the Balkans, for example, has increased

Joseph J. Kaminski (iD) is associate professor and department chair of international relations at the International University of Sarajevo. He can be reached at jkaminski@ius. edu.ba. dramatically in recent years: 39 FUs were established in Turkey alone between 2003 and 2012 (Birler 2012). According to the Turkish Council of Higher Education, as of 2019, Turkey had 77 officially recognized FUs (YÖK 2019). English is the language of instruction at many FUs and these institutions often actively seek native English speakers with terminal degrees from the United States. This type of faculty attracts students and brings legitimacy to these newer schools.

An FU can be an attractive option for teaching and serviceoriented academics who seek an alternative to working in the West. As the academic job market in the United States continues to contract, more freshly minted PhDs-especially those from midand lower-ranked departments-likely will be looking abroad for their first full-time position. FUs in places such as the Balkans do not pay the high salaries offered in more popular Middle Eastern ex-pat academic destinations. However, these jobs do enable you to live comfortably and save a respectable amount of money in your new country of employment.

Western academics first must understand that a full-time position in an FU is not the same as a tenure-track position in the United States. Although some FUs offer longer-term contracts, most contracts for foreign faculty are more akin to adjunct contracts that are renewed annually or semi-annually. Although contract renewal becomes a formality after a few years of working at an FU, this reality must be considered before applying for a job. Once you are offered your first full-time job with a reasonable 
salary, the emotional satisfaction of feeling wanted makes rational thinking on this matter more difficult.

Concerning the realities of research in developing countries, Altbach $(2003,4)$ commented that whereas some academics working in the developing world have made important scholarly contributions, peripherality still means that they "will seldom be at the frontiers of world science and will not share in the control over the loads and regularly publish because publications raise the global rankings of these newer universities. In some countries, academic promotion necessitates meeting certain regional or national requirements. Where I work, the regional law of higher education stipulates that an assistant professor, while holding that rank, must publish five articles, one book, mentor one master's thesis, and complete a project-which is completely undefined and left to the

\section{An FU can be an attractive option for teaching and service-oriented academics who seek an alternative to working in the West. As the academic job market in the United States continues to contract, more freshly minted PhDs-especially those from mid-and lower- ranked departments-likely will be looking abroad for their first full-time position.}

main levers of academic power worldwide." He also noted that despite the limitations that many schools in the developing world face, " $[\mathrm{t}]$ he European and increasingly the American academic model-based on departments, competition among academic staff, institutional hierarchy, and specific definitions of science and scholarship"-are still the models that most of the developing world follows today (Altbach 2003, 4). I think he is correct; you often hear senior administrators speak of research expectations that they themselves likely never could meet. The real problem is this: How do you produce R1-level research without many of the resources you would find at an R1 institution? The short answer is: You will not.

Throughout my experience in the Balkans as a full-time faculty member who also has been on numerous short academic exchanges at other regional institutions, I have noticed that whereas most FUs have some library and database resources, these resources overall are woefully insufficient for producing top-level research. Along with tenure (as understood in the American sense) not really existing, higher administration often will even be unfamiliar with the idea of sabbatical. One bewildered administrator commented after I inquired about sabbatical at their institution, "So, in America, you get paid to not work for a semester? That's amazing!" I was stunned by this bemused response to my seemingly innocuous question; however, I now understand his response. Output and productivity often are measured by physically being on campus as opposed to conducting off-campus fieldwork, data collection, and archival research. The prevailing perception is that off-campus research should be done in your free time.

\section{PUBLISHING IN “INDEXED” JOURNALS}

The traditional US teaching-focused university that emphasizes heavier teaching loads and significantly lighter research expectations does not exist in many FUs in developing countries. Professors are expected both to teach 3-3 (and sometimes even 4-4) course discretion of the respective university-within a five-year appointment period with one possible reappointment to be eligible for promotion to associate professor (Službene Novine Kantona Sarajevo 2017). The higher administration of each university has final say on granting promotion and is under no obligation to promote you simply because you meet the minimum legal requirements.

These minimum criteria to be eligible for promotion may sound significant; however, you must remember that the standards for what constitutes good research in the developing world are quite different than in the United States. Few political scientists working in the Balkans regularly publish solo-authored articles that appear in the Social Science Citation Index; Scopusindexed articles produced by multiple coauthors are considered more than acceptable. Deans regularly remind you about the importance of publishing in indexed journals, but which indices count as relevant often remains unclear (e.g., see table 1). Almost any nonpredatory (and even sometimes predatory) journal in existence is likely to be indexed somewhere: for example, EBSCO, Ulrich's Periodicals Directory, and Central and Eastern European Online Library. This also means that newer journals not yet indexed risk being perceived as illegitimate even if they are not. Promotion committees often read only the name of the index in which your article is listed, with little concern for the actual quality of the article. Book chapters-even with top university pressesoften fall into a gray area and count for less than they should.

The epidemic of unethical publishing practices that continues to plague the developing world has been well documented (Balehegn 2017; Beall 2013; Xia et al. 2015). In one final-round interview with a university in Southeast Asia a few years ago, a dean told me that I was expected to produce three Scopus-indexed articles every year. When I politely told him that this was an unreasonable standard for a position that entails a 3-3 teaching load and administrative duties, he told me not to worry: most people meet the requirement by

Table 1

Commonly Recognized Indices in the Balkans that Contain Political Science Articles

\begin{tabular}{ccc} 
Academic Search Premier & Arts \& Humanities Citation Index & Social Sciences Citation Index \\
\hline Scopus & EBSCOhost & Ulrich's Periodicals Directory \\
\hline European Reference Index for the Humanities & Central and Eastern European Online Library & Current Contents/Social \& Behavioral Sciences \\
\hline JSTOR & Emerging Sources Citation Index & Serbian Citation Index \\
\hline
\end{tabular}


"including their friends" in their research. Puzzled by this, I asked a colleague with previous teaching experience in this region what the dean meant. He told me that this was a well-known local euphemism for quid pro quo exchanges for coauthorship: you put my name on your solo-authored article, I put your name on my solo-authored article and-presto-we both have two articles. If you do this with three or four different "friends," you will have an impressivelooking research output. Obviously, this is unethical, and I did not accept that job offer.

As shown in the previous examples, there is a clear disconnect between publication expectations and reality. Despite efforts to follow the Western model, as Altbach $(2003,5)$ noted, "academic work [in developing countries] for the most part takes place in a national context at universities that, while affected by global trends, nonetheless work on a day-to-day level in their own context." What may be popular in American departments often will not be in Albania. Whereas it is critically important to build strong professional networks early in your career in any locale, it is even more critical when you work in a developing country. If you do not stay connected to relevant professional networks within your subfield, in time you will become increasingly out of touch with the more well-known gatekeepers of the discipline and find yourself working within the general standards of the local context in which you are situated. This may be acceptable for some ex-pat with which they first came into the profession. This can be a difficult reality for many research-oriented Western academics who took for granted their previous library, database resources, and internal funding streams. Before accepting any job in a developing country, you first must take stock of your career goals before putting yourself in a position where you will never be able to achieve them. If you seek to be competitive for a future position at an R1 institution, perhaps starting your career at an FU is not the best option. This situation, which I have witnessed firsthand, often leads to resentment, which almost always transfers into professional working relationships and eventually even into the classroom. Conversely, if you prioritize teaching and service, an FU could be a good fit. It is impossible to adequately comprehend what the working conditions are like in a developing country without experiencing them firsthand. Patience, an open mind, and full cognizance regarding mitigated publishing opportunities are prerequisites to a successful professional experience in a developing country.

\section{RESPECT IS EARNED, NOT GIVEN: HOW TO SUCCEED IN THE CLASSROOM}

This final section offers advice on how to be successful in an FU classroom in a developing country. It is important to point out that being a male made it significantly easier for me to adjust. As in Western institutions, the female faculty I have met working at FUs

\section{If you do not stay connected to relevant professional networks within your subfield, in time you will become increasingly out of touch with the more well-known gatekeepers of the discipline and find yourself working within the general standards of the local context in which you are situated.}

academics, especially those proficient in the local language. The problem is that this can result in a CV that five years later makes you uncompetitive for a job at a research-intensive institution, if this is your goal. Therefore, I emphatically recommend to all newly admitted PhD students to start building a strong scholarly network as soon as possible via relevant social media platforms in your particular subfield and to stay informed about which articles these scholars recommend, which conferences are transpiring, and other important news that you may miss if you are teaching abroad.

Therefore, whereas administrators often speak of research excellence, this ultimately is more likely to be a lofty aspiration. It is important for Western academics, especially those who are few in number at their new institution, to advise administrators about which levels of institutional support are required for top-level research output. Although foreign faculty often have limited access to the higher rungs of institutional governance (Altbach 2003), it is important to remember that you were hired not only to teach but also to offer your unique perspective to higher administration regarding ways to improve the university. Recommendations must be given respectfully so you are not perceived as an obnoxious know-it-all to those who might not be familiar with your intentions.

Younger scholars who prioritize research output and who take a position at a newer, private institution in the developing world must accept that they likely will never achieve the publication goals almost without exception report facing a more difficult experience than their male counterparts. They report that they have more challenges from students who do not respect their authority and administrators who do not value their input than in their previous academic employment. I also began this position as a single male with a US passport and no children. Visa issues, preexisting debt, healthcare considerations, and schooling for your children can make relocating abroad a more complicated choice.

Foreign academics must first earn the respect and trust of their students. Students from countries such as Bosnia and Herzegovina and Kosovo often have difficulty understanding how an American with a $\mathrm{PhD}$ from an American institution could possibly choose to work in their country. How could they leave the "land of milk and honey"-which most perceive the United States to be-for what even first-year undergraduates know are more difficult working conditions? After only a few days on the job at my current university, I realized that I would need to earn my students' trust and doing so would not be the same way I had succeeded in earning it in US institutions. Simply being a nice person and fair grader is not enough; you need to earn your students' trust by demonstrating cultural sensitivity and awareness of their personal struggles. You also need to be open to sharing your personal background. Students like to hear your life story. Knowing that you are comfortable in telling them about some of the challenges that you faced when you were in their position puts them at ease. 
Another advantage I had was related to the fact that I share the same religious affinities as most of my students. Nevertheless, rumors circulated about who I was and for whom I was working. These concerns cannot be assuaged by simply declaring, "I am not a CIA spy, no worries!" Your opening lecture at your new university will be far more important than it would be at an established Western institution, where your presence in the classroom is not section into English using Google Translate, she did not need to give the original author credit. Because she rewrote it in English, it was now her idea and not the original author's. Many similar puzzling cases will arise. Wise professors dealing with numerous inevitable and obvious cases of plagiarism in their first semester will redesign their course assignments to mitigate the possibility of plagiarism. Instead of assigning an introductory class a long

\section{Simply being a nice person and fair grader is not enough; you need to earn your students' trust by demonstrating cultural sensitivity and awareness of their personal struggles. You also need to be open to sharing your personal background.}

particularly unique. You need to have a good explanation for why you chose to work in their country; a good paycheck and a desire to travel are inadequate. Being honest with your students about why you are teaching at their university is a good icebreaker that can build trust. A critical first step to earning their trust is articulating concisely and sincerely that you are nervous too and that you also will learn from them.

You must immediately abandon any pretense of considering yourself as someone the students are "lucky" to have teaching them. Students from developing countries can read body language as well as American students. I argue that they are even better at assessing their professor because many have limited English skills; therefore, they focus more on body language and nonverbal cues than the actual content of the professor's speech. An arrogant American is a professor hated by students and perceived as an extension of empire. These professors also do not have their contract renewed despite multiple top-level publications. Moreover, at institutions that do not seek to be renowned as global hubs of cutting-edge research, your publications may be resented by other faculty if too much time is spent self-promoting. Top-level publications will not guarantee a contract extension if your classroom performance and university service are perceived as lacking.

The work ethic and overall expectations of students also differ dramatically from previous classroom experiences in the United States. Certainly, there are many diligent and serious students who view education as their only way to a better life. I have helped a few bachelor's students get into some excellent master's programs in Europe, where they have graduated in the top of their class at Central European University and Royal Holloway, University of London. However, most of the students I encounter possess limited student skills. This does not suggest that they are unintelligent; rather, they often lack a basic understanding of how to take notes or what test preparation entails. Whereas many professors in the United States complain about student readiness for college, I can state with absolute certainty that what you will experience in a newer FU in a developing country is not comparable.

Before entering the classroom, there are other things you must consider. First, you cannot expect students to pay \$200 for books. You need to figure out inexpensive ways to provide students with the readings. Second, plagiarism-a word that conjures fear in most American students-is rampant in developing countries, even at the better universities. Many students genuinely do not know what plagiarism is, and a brief workshop defining what is and is not plagiarism is not sufficient. One student who plagiarized an article written in Turkish claimed that because she translated that research paper that many students will lack the capacity to write, you should focus more on assignments and activities that can be directly monitored (e.g., in-class quizzes, simulations, projects, and short reflective papers). This may sound like pandering to bad students but, in reality, you are doing a service. The American classroom model and its incumbent expectations cannot simply be assumed in a classroom of students with no prior exposure to the American system.

It also is imperative to build good working relationships with local faculty, regularly seeking their advice. Make the effort to learn the local language and approach your new colleagues about coauthoring possibilities. You likely will have different skillsets that complement one another. Foreign professors should study previous syllabi, in-class activities, and assignments created by local faculty for guidance. You must adjust to your institution; your institution will not adjust to you. Institutional transformations take time: be patient and focus on steadily building a culture of classroom excellence rather than expecting it to develop overnight. Finally, it is important to mention that students in FUs often have more direct access to high-level management and even boards of trustees than typically at a US institution. Certain wellconnected students will not think twice about telephoning someone that you as the professor would hesitate to contact. Students have more power to shape managerial decisions in many FUs because these schools often are strapped for cash, lack robust alumni donor bases, and do not have a large pool of students from which to draw. Whereas some US universities may receive more than 100,00o applications annually, many newer FUs depend on admitting almost every applicant simply to make ends meet. Students are aware of this; therefore, you must be extra attentive to their classroom performance.

\section{CONCLUSION}

Everyone has their own measure for professional success. I personally seek a healthy balance among teaching, research, and service. Whereas an FU might not be appropriate for someone who aspires to be a world-renowned researcher, for those who are adventurous and prioritize teaching and service, it might be the right choice. I have made myself at home in Sarajevo and even got married. This life has been good for me and it can be for you as well. Your gross salary likely will be lower than it would be in the United States, but this usually is offset by a significantly lower cost of living. You could easily attain yearly savings that are greater in a developing country than in a developed country where you could earn three times the gross salary. 
Gaining your students' trust and respect depends on your ability to trust and respect them to some degree. If your intentions are not pure and you are in it only for the money, I can assure you that you will burn out quickly. However, if you have a natural cultural affinity for where you will be working and a genuine desire to offer students from underprivileged or war-torn backgrounds a rich learning experience, then you have a real chance of succeeding. It can be stressful to leave the comfort of your native country, but it also can be an immensely rewarding adventure that helps you grow as a person.

\section{REFERENCES}

Altbach, Philip. 2003. "Centers and Peripheries in the Academic Profession: The Special Challenges of Developing Countries." In The Decline of the Guru: The Academic Profession in Developing and Middle-Income Countries, ed. Philip Altbach, 1-22. New York: Palgrave.
Balehegn, Mulubrhan. 2017. "Increased Publication in Predatory Journals by Developing Countries' Institutions: What It Entails? And What Can Be Done?" International Information \& Library Review 49 (2): 97-100.

Beall, Jeffrey. 2013. "Avoiding the Peril of Publishing Qualitative Scholarship in Predatory Journals.” Journal of Ethnographic \& Qualitative Research 8 (1): 1-12.

Birler, Ömür. 2012. "Neoliberalization and Foundation Universities in Turkey.” In Neoliberal Transformation of Education in Turkey: Political and Ideological Analysis of Educational Reforms in the Age of the AKP, ed. Kemal İnal and Güliz Akkaymak, 139-50. New York: Palgrave.

Službene Novine Kantona Sarajevo. 2017. "Zakon o Visokom Obrazovanju." Official Gazette of Sarajevo Canton: Law on Higher Education 33/17. Sarajevo: Skupština Kantona Sarajevo. Available at https://mon.ks.gov.ba/sites/mon.ks.gov.ba/ fileszakon_o_visokom_obrazovanju_ks.pdf.

Xia, Jingfeng, Jennifer L. Harmon, Kevin G. Connolly, Ryan M. Donnelly, Mary R. Anderson, and Heather A. Howard. 2015. "Who Publishes in 'Predatory' Journals?" Journal of the Association for Information Science \& Technology 66 (7): 1406-17.

YÖK. 2019. "Vakıf Yükseköğretim Kurumları." Turkish Council of Higher Education: Foundation Higher Education Institutions Report. Ankara: Ankara Üniversitesi Basimevi. Available at www.yok.gov.tr/HaberBelgeleri/Haber\%20\%C $4 \%$ Bo\% $\mathrm{C}_{3} \%$ A 7 erisindeki\%2oBelgeler/Yay\%C4\%B1nlar/2019/Vakif_Yuksekogretim_ Kurumlari_2019.pdf. 